\title{
Mithridates, Helianax And Late Hellenistic Delos As Global CITY: URBAN INSULARITY AND INTEGRATION FIELDS
}

Fábio Augusto Morales ${ }^{1}$

\section{ABSTRACT}

This paper discusses the theoretical problem of the mediation between macro and micro scales of analysis in Global History, centered on the analysis of the temple of Mithridates dedicated by a certain Helianax in 102/1 BC in the Samothrakeion of Delos. After describing the available archaeological and epigraphical evidence, the paper discusses the concepts of (urban) insularity, world/global city, and integration fields, in order to explore their explanatory power for the analysis of the integration fields and modes of integration visible in Helianax's dedication.

\section{KEYWORDS}

Urban insularity, Integration fields, Hellenistic Delos.

1 Lecturer of Ancient History at the Federal University of Santa Catarina, Brazil. Email: fabio.morales@ufsc.br. 
Mare Nostrum, ano 2021, v. 12, n. 2

\section{Introduction}

The emergence of Global History as a distinct field in the last decades has attracted the attention of many historians who have been, in their respective fields, engaged in the critique of eurocentrism and methodological internalism ${ }^{2}$. Ancient historians were no exception. Struggling against the role eurocentrism played in its constitution since, at leats, the 1980's, the field of Ancient History recently saw the profusion of works promoting a dialogue with the field of Global History regarding either the macrocomparison between cultures or empires ${ }^{3}$, or the study of ancient 'globalizations', networks, circulations, world-systems, and connections ${ }^{4}$. As expected, many critical questions made against Global History (Drayton \& Motadel, 2018) were received by global-inspired Ancient Historians: do global approaches suppress local specificity, shortterm processes, political frontiers, and individual agencies? Are global histories limited to 'globalized' social elites or exceptionally 'global' individuals? Do meanings and symbols play a role in Global History? These questions, which in a sense reflect the anxiety of cultural and social historians towards a supposed resurgence of the twentieth century, political/economic-oriented, and macro-scaled World History (inspired by either Braudel or McNeill, despite the deep differences; see (Mazlish, 1998), have fomented the construction of a very diversified set of approaches and models, both in Global History and in global-inspired Ancient History. This paper intends to contribute to this debate by exploring the mediations between micro and macro scales of analysis. Here, the micro scale is constituted by the analysis of a tiny building dedicated in a tiny sanctuary located on a tiny island, active for little more than a decade - the temple ${ }^{5}$ of Mithridates of Pontus in the Delian Samothrakeion, dedicated in 102/1 and abandoned (probably) in 89/88 ${ }^{6}$. The macro scale, in turn, focuses in the many integration fields (re)produced through that building, namely the fields of Athenian cleruchies, Hellenistic euergetism, East

\footnotetext{
${ }^{2}$ Cf. Amin, 2011; Anievas \& Matin, 2016; Beckert \& Sachsenmaier, 2018; Belich et al., 2016; Conrad, 2016; Crossley, 2008; Karras et al., 2017; Olstein, 2015; Sachsenmaier, 2011).

${ }^{3}$ Cf. Bang \& Bayly, 2011; Hansen, 2000; Hansen et al., 2002; Lloyd et al., 2018; Mutschler \& Mittag, 2008; Scheidel, 2009.

${ }^{4}$ Cf. Constantakopoulou, 2017; Guarinello, 2010; Hodos, 2006; Hodos \& Geurds, 2017; Horden \& Purcell, 2000; Knappett, 2011; Knappett \& Society for American Archaeology, 2013; LaBianca \& Scham, 2014; Leidwanger \& Knappett, 2018; Pitts \& Versluys, 2014; Purcell, 2016; Vlassopoulos, 2013; Wilkinson et al., 2011).

5 The building is often called 'monument' or 'heroon' of Mithridates (e.g.(Erciyas, 2001; Roller, 2020). However, as Bruneau ( 1970, p. 399) pointed, the dedicatory inscription mentions a naos in honor of Mithridates Eupator Dionysos.

${ }^{6}$ All dates are B.C., unless otherwise indicated.
} 
Mediterranean trade, Greek religion, and West Afro-Eurasian empires, which articulated cities from Rome in the west to Nisa in the East (fig. 1). Bearing in mind these two poles, the paper discusses one of their mediations, namely, the 'global city' mode of integration (a concept borrowed and adapted from contemporary Urban studies), built upon the particular features of the Delian urban insularity in the Late Hellenistic period.

Therefore, the paper starts with a description of the building based on its archaeological and epigraphical remains. Then, it discusses the concepts of urban insularity, global city and integration fields in order to offer a global-inspired theoretical framework for the mediations between macro and micro scales. Finally, it articulates micro and macro scales, discussing the meaning of the temple both to the history of the urban development of Delos and of the Mediterranean integration under Roman rule.

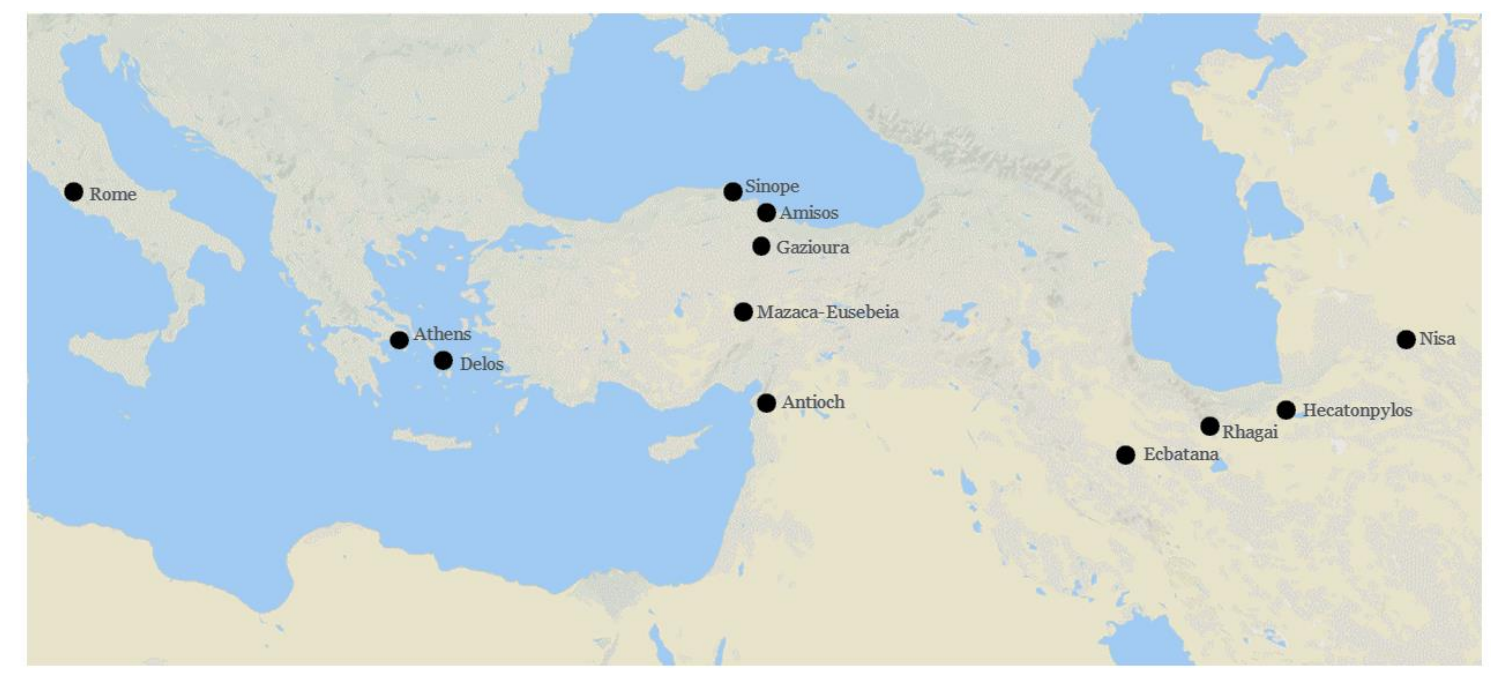

Figure 1: Cities mentioned in this paper.

\section{The monument of Mithridates in the Delian Samothrakeion}

Located near the narrow watercourse of Inopos, between the Theatre Hill and the foot of the Mount Kynthos at Delos (fig. 2), the Delian sanctuary of the Great Gods of Samothrace received in 102/1 the addition of a new building. The inscription on its architrave reads:

ID 1562:

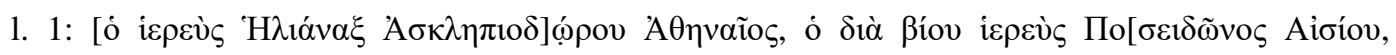

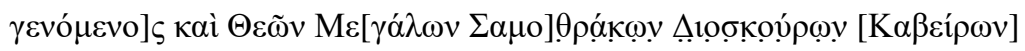


Mare Nostrum, ano 2021, v. 12, n. 2

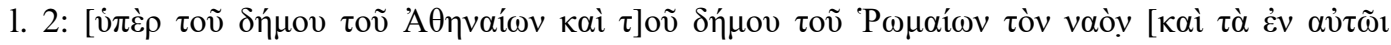

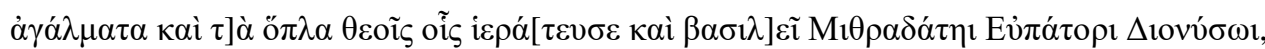

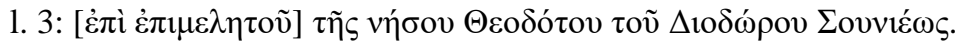

The priest Helianax, son of Asklepiodoros, an Athenian, priest for life of Poseidon Aisios, having become also the priest of the Great Gods of Samothrace, the Dioskouroi Kabeiroi, / on behalf of the demos of the Athenians and the demos of the Romans [dedicated] the temple and the statues in it and the weapons to the gods whom he has served, and to the king Mithridates Eupator Dionysos. / When Theodotus, son of Diodoros of Sounion, was epimeletes of the island. (trans. by A. M. (Sitz, 2017, p. 242).

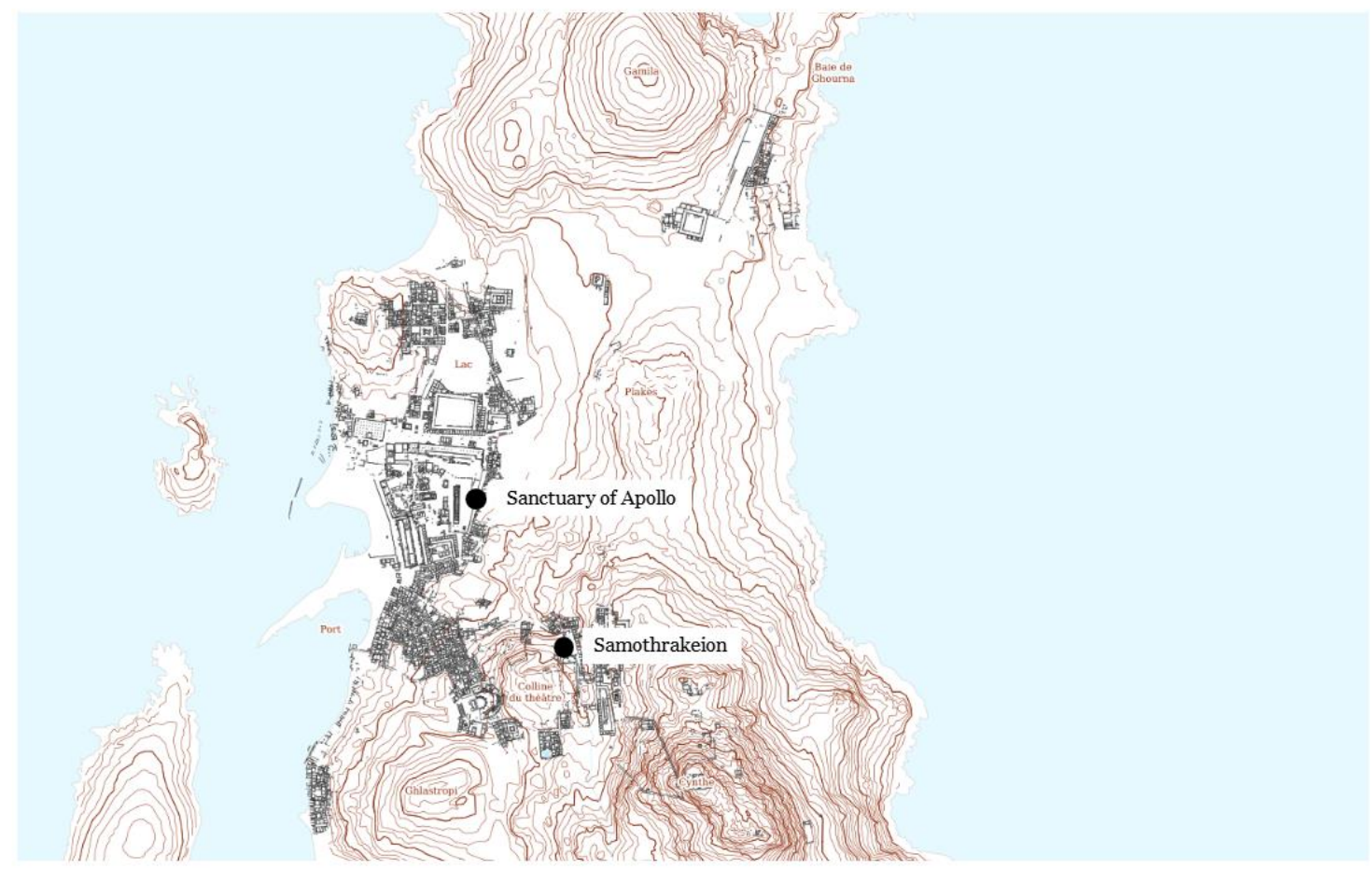

Figure 2: Plan of Delos, from the $S I G$ de Délos (École Française d'Athènes), available at http://www.sigdelos.efa.gr.

The dedicant, Helianax of Athens, son of Asklepiodoros, is mentioned in only one inscription aside from those from the Samothrakeion: he appears as the dedicant of a statue for Antiochos VIII of Syria and his wife Kleopatra in the sanctuary of Apollo, dated also to 102/1 (ID 1552). There is no consensus about Helianax's family background, but a Delian inscription of 160/159 (ID 1555) may offer a clue: three Rhodian citizens, a 
certain Agathanax, son of Epigenes, and the brothers Asklepiodoros and Hermogenes, sons of Asklepiodoros, made in that year a dedication to Laodike, sister of the king Pharnakes II and sister-wife of Mithridates IV of Pontus, in the Delian sanctuary of Apollo. Considering that the father of Helianax was one Asklepiodoros, son of Asklepiodoros (as indicated by one of the inscriptions inside the temple of Mithridates), F. Durrbach suggested that the above-mentioned Asklepiodoros and Hermogenes were actually the grandfather and grand-uncle of Helianax (Durrbach, 1921, p. 106). As Roller points out, by dedicating a statue of a Pontic queen at Delos (recently turned a free port by Rome and put under Athenian administration in 167), the two Rhodian brothers connected the Pontic kingdom with the great island powers of the era - Rhodes and Delos - as well as with Rome and Athens (Roller, 2020, p. 77). If the hypothesis is correct, Helianax came from a Rhodian family with Pontic connections whose members were made Athenian citizens around the middle of the second century (Mattingly, 2004, p. 47). Thus, the dedications to Mithridates VI added a new step in the Helianax family's established relations with the Pontic kingdom.

The inscription identifies Helianax as priest of two cults: he was a lifelong priest of Poseidon Aisios, and appointed priest of the civic cult of the Samothracian gods in Delos for the year 102/1. In the cult of Poseidon Aisios, 'auspiciousness' (probably related to safe seafaring) is attested only at Delos and in association to Helianax. The lifelong duration of its tenure raised controversy on the civic or private, Greek or oriental nature of the cult (Bruneau, 1970, p. 265; Parker, 2017, p. 157, n. 19). The history of the Samothrakeion and its cults (to the Great Gods of Samothrace, the Cabeiri, and the Diouskouri), in turn, is less obscure, although considerably confusing. Discovered in 1882 by S. Reinach and excavated in 1909 by J. Hatzfeld, the remains of the sanctuary were published by F. Chapouthier in $1935^{7}$. Three building stages are known. The first is dated to the middle of the fourth century, when an enclosure was built in the location comprising two terraces, the lower one limited by a semi-circular wall and the upper one dominated by a marble tetrastyle doric rectangular building, wider than it is deep, with the entrance and porch on the longer side. Although identified by Chapouthier as a temple, it was later interpreted as a hestiatorion, or dining chamber related to the cult. The second phase starts shortly before 131 , when the building was extended to the south, receiving a

\footnotetext{
${ }^{7}$ The excavation history and lengthy description of the remains can be found in Chapouthier (1935).
} 
niche left to the entrance. The third and final phase started with the construction of the the temple of Mithridates in 102/1, annexed perpendicularly to the earlier temple. The name Samothrakeion, however, appears only in the second-century inscriptions, associating the cult of the Great Gods with the Cabeiri (from Anatolia) and the Dioskouroi. A third century inscription mentions a 'Kabeirion facing [Mount] Kynthos, suggesting that the first phase sanctuary was dedicated to the Anatolian chthonic gods known as Kabeiroi. While the assimilation of the Kabeiroi and the Great Gods of Samothrace is attested in the Classical period (e.g., Herodotus, 2.51), their assimilation to the Dioskouroi appears to have occurred only after 167. Bruneau associated it to the Samothracian diaspora in the Hellenistic period (Bruneau, 1970, p. 395), Cole interpreted it as an Athenian innovation, due to the radical change in the local community of worshippers after the expulsion of the Delians in 167 (Cole, 1984, p. 79) ${ }^{8}$. All the twelve known priests of the Great Gods are Athenians, but it is interesting to note that Helianax is the only one not identified by his deme (Bruneau, 1970, p. 397). The location of the sanctuary, near the watercourse of the Inopos, must have been dictated by cultic needs. In the same period and probably in connection to the sanctuary's building, a reservoir for the Inopos' waters was built a few meters away, thus diminishing the difficulties arising from summer droughts.

The mention of the act 'on behalf the demos of the Athenians and the demos of the Romans' points to the special relationship between Athens and Rome during the Second Athenian Domination. Rome gave the administration of Delos (along with Imbros, Lemnos, Skyros, and Haliartus) to Athens in 167/6, acknowledging its support during the Third Macedonian War, in contrast to Pergamon and Rhodes, which would be increasingly overlooked by the Senate. The Delians were expelled from the island possibly by violence - and settled in the Peloponnese (Gettel, 2018; Habicht, 1997, p. 216-219). The Athenians sent a group of colonists and established a new government

\footnotetext{
${ }^{8}$ The dating of the first stage in the fourth century was suggested by Chapouthier, following the analysis of architectural remains made by R. Vallois - who didn't define a terminus post quem before the end of the Archaic period (quoted in CHAPOUTHIER, 1935, p. 78). Given the scarcity of clear direct links between Delos and Samothrace in the classical period (Cole, 1984, p. 77), it is tempting to associate the construction of the sanctuary, or at least the association of the Kabeirion to the Great Gods, with the huge building program that followed the liberation of Delos from Athenian rule in the late fourth century (Constantakopoulou, 2017, p. 57-110; Moretti, 2015), especially considering the importance of the Samothracian mysteries to the dynastic identity of the Macedonian kings (Ginouvès, 1993, p. 197-213), who at the time were deeply involved in Cycladic geopolitics and were responsible for the funding - if not the construction itself - of monumental buildings at Delos between the fourth and third centuries.
} 
with an island governor (selected from the group of former Athenian archons) and officials in charge of public finances, the port and markets, the temples, and the gymnasium and competitions. Throughout the second century, other groups of residents were integrated in the government, as seen in the decrees passed by the Athenian cleruchs in addition to Romans and other foreigners (Habicht, 1997, p. 248-250). By granting the island to Athens, the Roman Senate also turned it into a free port, which, associated with the destruction of Corinth in 146, made Delos the most important Eastern Mediterranean center of trade of the second half of the second century, especially for the trade of slaves (from the Black Sea, Anatolia, and Syria) and oriental-manufactured goods directed to Italy (Bruneau et al., 2013; Kay, 2014, p. 197-213; Rauh, 1993, p. 41-68; Zarmakoupi, 2018b). The foreign colonies at Delos created many associations, but undoubtedly the more powerful was the Italian colony, whose power could be seen in in the so-called Agora of the Italians, the largest building of the island, constructed just north of the Sanctuary of Apollo.

The inscription then mentions the dedication of a naos, statues and weapons to the gods served by Helianax (i.e., Poseidon, the Great Gods, and the Dioskouroi-Kabeiroi) and to Mithridates VI Eupator Dionysos, the king of Pontus and the then hegemonic power in the central Black Sea (Ballesteros Pastor, 2018a; Christodoulou, 2015; Erciyas, 2001, 2005; Højte, 2009; McGing, 1997; Roller, 2020). Pontic kings were already honored in Delos, both before and after 167 (Habicht, 1997, p. 253), but Mithridates VI had no parallel. As Ballesteros Pastor have showed, by having extended the empire over central Anatolia and the coasts of the Black Sea, fighting Scythians, inheriting the diplomatic relations of his dynasty, and building a cosmopolite court, Mithridates VI could represented himself simultaneously as champion of Greek culture and religion, heir of the Persian and Anatolian kings, and friend of Rome (Ballesteros Pastor, 1995, 1998, p. 59, 2006, 2018a, 2018b). His increasing power over Anatolia, however, would eventually lead to a conflict with the neighbor kingdom of Bithynia. The Roman intervention in favor of the Bithynian cause pushed Mithridates to declare war against Rome, which included the slaughtering of thousands of Italians residing in Asia Minor in 89. The so-called Mithridatic Wars included two invasions of Delos by Pontic or Ponticallied forces, in 89 and 69; though essaying a recovery after the first invasion, Delos would have permanently lost its commercial centrality as well its huge population, being for the centuries ahead a symbol of solitude (Bruneau, 1968). At 102/1, however, the war between Mithridates and Rome was not on the horizon, and joint dedications to both 
Mithridates and Rome were not uncommon (Verdejo Manchado \& Antela-Bernárdez, 2015).

The naos, in turn, built perpendicular to the Samothrakeion's hestiaterion, was an ionic distyle temple in antis, with a slightly rectangular plan of only $4.30 \times 3.05 \mathrm{~m}$, with an elevation of $4.65 \mathrm{~m}$ (fig. 3). In its pediment and in all inner walls stood busts inserted in concave shields or medallions (fig. 4), each one with its own inscription: one in the pediment, six in the back wall, and three in the each of the side walls (Chapouthier, 1935; Erciyas, 2001, p. 104-115; Kreuz, 2009). The inscriptions, in irregular states of conservation, identify the honored and repeat Helianax's dedication formula. The bust in the pediment, instead of representing Mithridates himself, represented an (due to the inscription's fragmentary state) unknown citizen of Amisos. The inner shield busts represented a curious sample. In the north wall stood the busts of Diophantos, son of Mithares, from Gazioura (residence of Pontic kings in northern Anatolia, near Amisos); the king Ariarathes VII of Kappadokia, nephew of Mithridates VI of Pontus, whose main capital was Mazaca-Eusebeia; the king Antiochos VIII Epiphanes of Seleucid Syria, whose capital was Antioch; Asklepiodoros, father of the priest Helianax, from Athens; an unidentified person; and an unidentified official of the Parthian court (whose main royal urban centers at the time were Nisa, Hecatompylos, Rhagai and Ecbatana). In the east wall stood the busts of an unidentified member of the court of Mithridates II of Parthia; another unidentified person; and Papias, son of Menophilos, from Amisos, friend and physician of Mithridates VI of Pontus. In the west wall stood the busts of Gaios, son of Hermaios, from Amisos, member of the court of Pontus; an unidentified secretary of Mithridates VI of Pontus; and Dorylaos, son of Philetairos, from Amisos, nephew of Dorylaos Taktikos, friend of Mithridates VI of Pontus and supreme commander of the Pontic forces. Only one of these portraits survived, though in a very damaged condition, which points to a probable damnatio memoriae related to the Mithridatic Wars. The places and individuals mentioned point to the extension of Helianax's network: Athens, royal urban centers of Anatolian, Syrian and Iranian kings; royal physicians, military commanders, and specific Anatolian cities such as Amisos, a former Milesian colony on the south shore of the Black Sea and important trade center for the Pontic kingdom, and Gazioura, residence of Pontic Kings in northern Anatolia. 


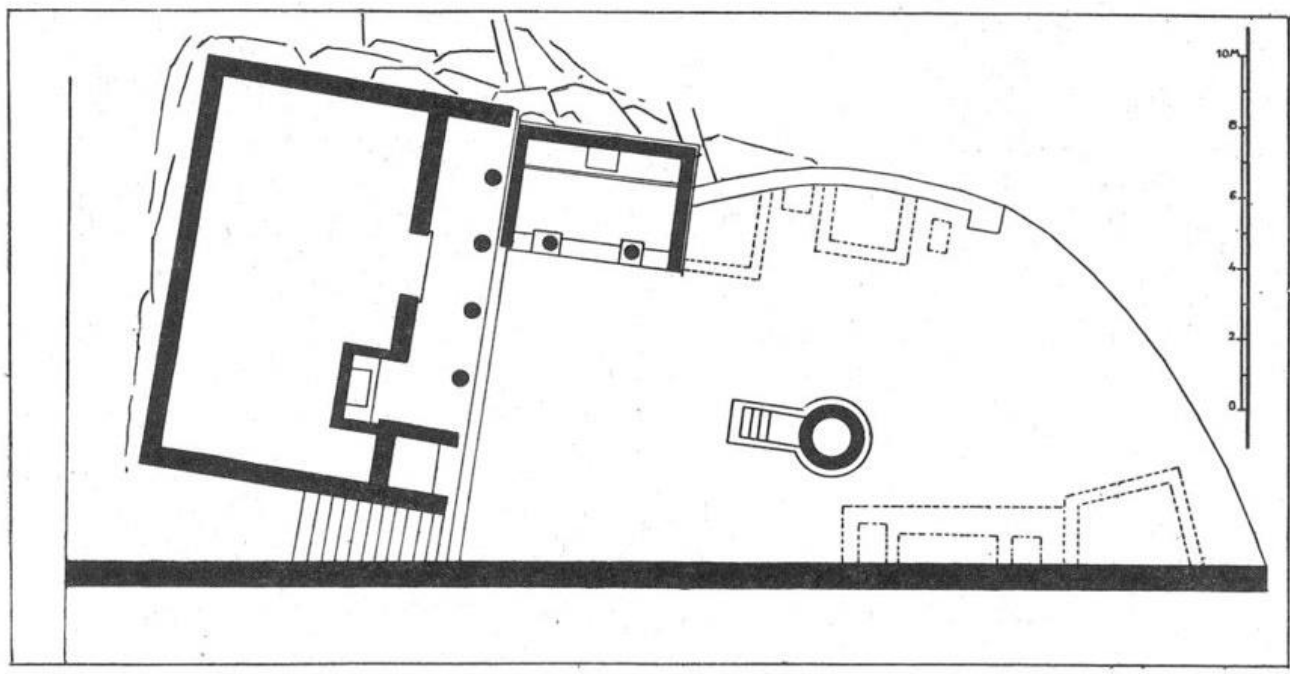

Figure 3: Plan of the Samothrakeion in the second century BC (Chapouthier, 1935, p. 85, fig. 107).

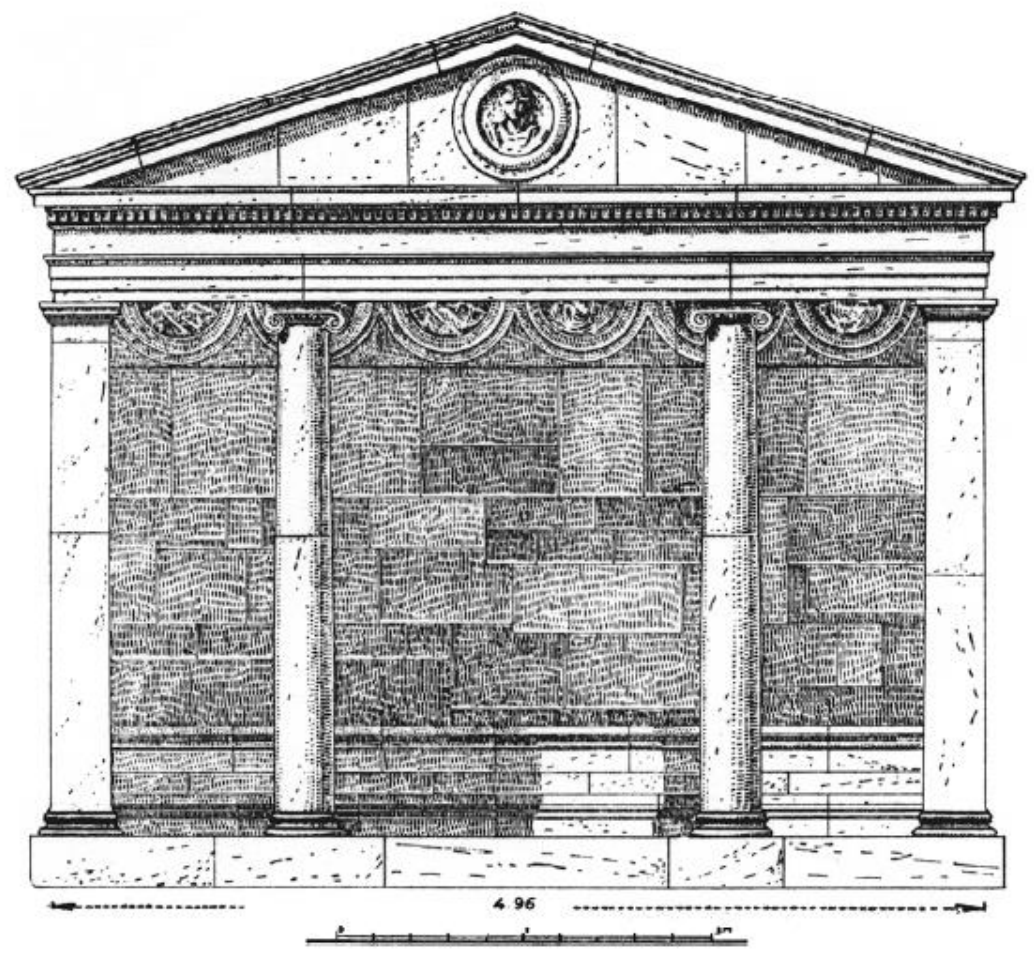

Figure 4: Reconstruction of the Temple of Mithridates - elevation (Chapouthier, 1935, fig. 56).

Inside the building, a marble bench or continuous statue base of $60 \mathrm{~cm}$ high was stuck on the walls. In the center of the north segment, on the longer wall, an inscription reads:

ID 1563:

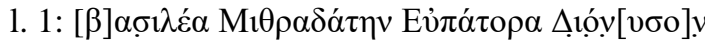


Mare Nostrum, ano 2021, v. 12, n. 2

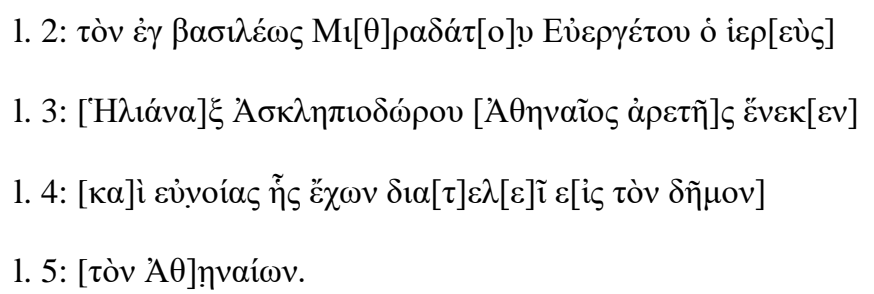

[Dedicated to] king Mithridates Eupator Dionysos, son of the king Mithridates Euergetes, by the priest Helianax son of Asklepiodoros, from Athens, for his continuous excellence and benevolence toward the Athenian people.

Above this inscription probably stood a free-standing statue of Mithridates VI himself, though no fragment was unequivocally identified. Pieces of two marble cuirassed statues were found near the Samothrakeion, carved with similar features of the contemporary statue of C. Bilienus displayed in the Agora of the Italians. However, their sizes didn't match the measures of the naos' base (Marcade, 1969, p. 331-333). The fact that the base is continuous along the three walls could indicate the existence of two other statues in the west and east walls, either of Pontic officials or of the Dioskouroi, but no additional inscriptions or fragments were found.

The location of the building, the origins of the individuals mentioned in the inscriptions, the offices held and the royal courts involved are revealing about the network of a local member of the Delian elite, as well as the ways the island connected itself to the wider world. These connections, however, were neither direct or mechanical; they were modulated by the particular urban insularity of Delos and its relations to the concrete Mediterranean integration processes. In order to support the discussion of the particular mediations between the dedication of the temple of Mithridates and its wider contexts, the next section will discuss the concepts of (urban) insularity, global city and integration fields.

\section{Urban insularity, global city, integration fields}

The concept of insularity has a long and complex history in the social sciences (Baldacchino, 2004, 2018). It should be noted, however, the tension between the notions of isolation and connection, on the one hand, and of natural constraints and social fact on the other. From the common topoi of isolation and smallness, based on images of oceanic small islands with little if any contact with continental societies, in the last decades Island 
Studies scholarship moved towards a view of islands as hubs of vibrant networks. The natural constraints of islands lost its central explanatory power due to the many ways societies manage to surpass and/or manage them (Patton, 2013, p. 33). In this sense, 'insularity' or 'islandness' began to be more associated with identity and discursive phenomena than to objective, natural factors. As Benoist put it, though insularity did not determinate the social development of islanders, they often see themselves as islanders (Benoist, 1987). Insularity has been defined as the set of cultural and symbolic features that shape insular identities in relation to, but not determined by, natural constraints (Constantakopoulou, 2010). Island Archaeology, for instance, shifted from a processualist emphasis on biogeographical factors to a post-processualist focus on meanings, taking islands and islanding as social and cultural processes (Boomert \& Bright, 2007; Patton, 2013, p. 17-18). On Cycladic archaeology, the groundbreaking study of C. Broodbank explored the many ways Cycladic societies built their cultural and social 'islandscapes' (a conceptual combination of land and sea) from Late Neolithic to Middle Bronze Age, discussing colonization histories, adaptation, demography and cultural variability (Broodbank, 2002). Other scholars, such as Chr. Constantakopoulou, A. Kouremenos, and others, have analyzed the interaction between culture and geography in the shape of particular insularities in the Cyclades from the Archaic to Late Imperial period, discussing topics that range from local constructions of the past and insular metaphors, to the role of insularity as practice and discourse in the creation of identities and religious, political and social networks (Constantakopoulou, 2010, 2017; Kouremenos, 2018; Kouremenos \& Gordon, 2020).

Though this cultural turn in Island Studies freed the field from geographic determinism and the hegemony of isolated, small oceanic islands as preferred objects, only recently scholars have been considering the fact that many big cities, both ancient and modern, were/are island cities. New York, Lagos, Amsterdam, Copenhagen, London, Paris, Stockholm, Tokyo, Guangzhou, Manila, Jakarta, Hong Kong, Shanghai, Singapore, Tianjin, Venice, Bruges, Rotterdam and so on are (or were) based on small river, maritime, or estuary islands; even the apparently mainland city of Mexico began as the lake archipelago of Tenochtitlan (Grydehøj, 2015). As A. Grydehøj and others have put it, 'strategically located small islands are so disproportionately likely to host major urban centers suggests that research into the islandness of such island cities could tell us something about cities in a broader sense' (Grydehoj et al., 2015, p. 9). Reflecting on urban formation processes in small islands, A. Grydehoj, for instance, suggests three 
types of spatial benefits that small, closetocontinent islands provide to cities: the water borders facilitate the territorialization and exercise of political authority of elites, which explains the great occurrence of island city capitals or island microstates throughout history; islands provide good conditions for territorial defense, as seen in the occurrence of fortresses in strategically located islands; the proximity to land and sea routes offers transport benefits to island cities, whose ports became important for whole mainland and archipelagic regions (Grydehøj, 2015). However, it should be noted the restriction, in urban island studies, to cases of early modern and modern island cities. Given the huge and increasing scholarship on Ancient Mediterranean cities, many of them island cities, it is reasonable to sustain that a dialogue between Ancient History and Urban Island Studies would be fruitful.

From the more obvious island urban landscape of Greek and Phoenician cities to the conjunctural 'insularity' of late fifth century Athens (Constantakopoulou, 2010, p. 137-175) and the Roman Empire under Tiberius at Capri (Campos, 2013; Houston, 1985), the interaction between insularity and urbanity played a key role both in urban formation processes and the integration of Ancient Mediterranean cities in the wider world, especially with the emergence of a 'connectivity paradigm' in the study of Ancient Mediterranean cities . Based on the critique of primitivist models of isolated and autonomies cities, late twentieth century scholars stressed the importance of Mediterranean networks and flows to the understanding of cities in their concrete, spatial contexts, being taken as places rather than (only) political entities (Morales \& Silva, 2020, with bibliography). This trend was amplified by the influential The Corrupting Sea by P. Horden and N. Purcell, published in 2000, which proposed a historical ecological paradigm of Mediterranean history: the extreme microecological fragmentation and unpredictability of Mediterranean weather, a constant during the millennia, pushed coastal and island societies to build storage institutions and maritime connections in different scales and through different modalities, from migration and trade to empire and religion (Horden \& Purcell, 2000). The critical reception of the book motivated the proposition of more nuanced models, from the study of 'Mediterraneanization' (Guarinello, 2003; Morris, 2003) to multiple 'globalization/glocalization processes (Vlassopoulos, 2013). The category of 'Ancient [Mediterranean] city', which Horden and Purcell preferred to treat as 'larger settlements and dispersed territories' (given the mutable nature of cities and their discontinuous economic territories; Horden \& Purcell, 2000, p. 89-122), was nonetheless maintained, though reinterpreted as hubs and nodes of 
dynamic networks (Osborne \& Wallace-Hadrill, 2013; Woolf, 2020; Zuiderhoek, 2017). Island cities, in this context, are particularly rich examples of connectivity and network patterns.

The emphasis on connectivity raises the issue of the relation between Ancient Mediterranean island cities and their networks. Here, it is worth considering the world/global city debate on contemporary cities, taken here for a comparative purpose. The concept of 'world city', popularized by the classical study of Peter Hall (Hall, 1966), was put in dialogue with world-systems theory in two papers, written by J. Friedmann G. Wolff (Friedmann \& Wolff, 1982) and J. Friedmann alone (Friedmann, 1986), and have since influenced many studies (Derudder et al., 2011; Knox \& Taylor, 1995; Taylor, 2003; Taylor et al., 2003). The authors argue that, rather than nation-states as territorial entities, the world-system was operated by a network of cities which directed the flow of capital and power. The world-system, in fact, is seen as a network of city-regions that articulate territorial economies with the global system. The centrality of world cities, visible in the concentration of multinational corporate headquarters and international financial institutions and agencies (Derudder, 2012, p. 73), is the expression of the power of their economic territories (Friedmann, 2001). A few years later, S. Sassen would publish her influential book The Global City (Sassen, 2001), drawing attention to the networks created by advanced services firms in many cities around the world, which enabled knowledge and technology to the functioning of the global economy. Those firms, which offered services such as international and local legal consulting services, financial services, technological support and so on, operated according to volatile rules (when compared to traditional multinational companies), working for specific short-term demands with global teams of experts with direct access to specialized knowledge. Thus, these offices, concentrated in the business districts of cities possessing high-technology communicational infra-structure all around the world, produced a myriad of global intrafirm networks that did not match the neat center/(semi)periphery hierarchies of the world system and its world cities (Sassen, 2005). As Derudder summarized it, the Global City, whose territorial basis is the cities' business districts, mainly differs from the World City in the defining key agents (advanced service firms $\mathrm{x}$ corporations), territorial basis (business districts x metropolitan regions), network structure (multiple networks x worldsystem hierarchy) and the potential de-territorialization aspect due to the importance of intra-firm global networks to its definition (Derudder, 2012). 
Mare Nostrum, ano 2021, v. 12, n. 2

The world/global city concepts, thus, refers more to modes of integration of a city in the world than to the nature of that city - despite its many ideological uses, from global city rankings to public policies to 'globalized' cities, often through varied forms of sociospatial segregation (Carvalho, 2000; Ferreira, 2007; Fix, 2007; Ghadge, 2019). A city must not be exclusively defined as a 'world' or a 'global' city, but rather it is integrated in the world through the 'world city', 'global city' and/or other modalities (migration networks, tributary systems, touristic and cultural poles and so on). Here, the meaning of the world/global city concepts as modes of integration is employed in order to highlight the different ways a city - or particular places in a city, with its own consequences to the urban landscape - can interact with the wider world(s), whether it is the capitalist interstate world-system, the global economy, the global society and culture, etc. The world city mode of integration modulates and directs the hierarchies of entire territorial economies and its national states, with the long-term accumulation of power and money being expressed in the urban space. The global city mode of integration, in turn, inserts a city in volatile and rhizomatic networks, being expressed in the urban spaces in high-tech districts that sprout up whenever the business environment is favorable and the infrastructure is available.

Naturally, in order to be applied to premodern contexts, both concepts should be adapted to integration processes that differ from contemporary global capitalism and its key agents. The scholarship on ancient integration processes is extremely varied, ranging from a single Eurasian world-system (Gills \& Frank, 1996) to multiple globalizations (Vlassopoulos, 2013), focusing on either trade networks, empires, or cultural communities. Here, I take two models I believe are particularly useful. K. Vlassopoulos, in his Greeks and Barbarians (2013), proposed the existence of fours 'worlds' of interaction to explain the multiple relations between Greeks and Barbarians from the Archaic to the Hellenistic period: the world of empires, the world of apoikiai, the world of networks, and the panhellenic world. In a nutshell, each world was defined by specific social actions and actors who (re)produced the flows of movement of people, ideas and goods from different 'currents of globalizations' which created different symbolic and material communities (koinai) through the varied glocalization processes around the Mediterranean (Vlassopoulos, 2013). N. Guarinello, in turn, in his Essays on Ancient History (2014), focused on the community formation processes through the negotiation of external (spatial) and internal (social) frontiers, accumulated over the centuries among Mediterranean societies. The Roman empire, for instance, is interpreted both as the result 
and as vector of a longer history of a Mediterranean integration process, managing complex and varied sets of civic, economic, ethnic, and cultural frontiers (Guarinello, $2010,2013,2014)$. On the one hand, while both authors seek to overcome the Eurocentric approach that isolate Greek and Roman societies from their Mediterranean framework, Vlassopoulos stresses the astonishing variability of the histories of Mediterranean globalization/glocalization processes (well beyond the Hellenicity/Hellenization paradigms), whilst Guarinello stresses unequal relations intra- and inter-communities as well the historical accumulation that produces social orders and frontiers.

In order to conjugate the potentiality of both models, it is worth to add a third support: Bourdieu's social fields theory. Though deeply marked by the methodological internalism of the twentieth century (Buchholz, 2008, 2016), the concept of fields is both elastic enough to deal with multiplicity and scale of Vlassopoulos' worlds and koinai (a field could have the limits of a house, a national state or the world economy; a society is crossed and constituted by many fields and subfields) and sufficiently consistent to consider the hierarchies of positions and varied capital accumulation forms implicated in Guarinello's frontiers (social agents build the field by competing with each other and defining the fields' rules and correspondent habitus). To highlight the inter-societal dimension of the fields which are the focus of this paper, I call them integration fields: fields that enable connections between different settlements, promoting synchronization processes and extending the localized particular social spaces. Integration fields - as social fields in general - do not correspond to functional spheres (economy, politics or culture; infra and supra-structures), but derive from structured and coherent social actions which form totalities, related to historically specific integration processes. Consequently, they must be defined from empirical, localized analysis of social practices facing the limits and possibilities of a particular context.

In the following section, an exercise of integration field analysis applied to Late Hellenistic Delos is proposed, discussing the particular mode of integration available to its residents and visitors through dedication of the temple of Mithridates in the Delian Samothrakeion. The dedication is seen as an example of the 'global city' mode of integration, based on subtle and volatile networks that unsettle fixed hierarchies in different fields. 


\section{The Delian Mithridateion in context}

Delos is traditionally presented as the archetypical commercial city of the Hellenistic period, with a cosmopolite population and intense commercial and financial activity. Rostovtzeff, for example, stated in 1941 that after the middle of the second century, Delos "ceased to be a Greek city-state and became an agglomeration of men whose connection with the island was temporary and whose interest lay in their business", and, as consequence, the island was no longer 'an appendix to the temple', because then 'it was in the harbour that the pulse of the community now beats' (Rostovtzeff, 1941, p. 790). Accordingly, the commercial prosperity of Delos has been taken as the key to interpret its urban growth. Recent studies on Delian urbanism have focused on the building activity related either to commercial activities or to the cosmopolitan community installed in the island due to its economic opportunities (Chankowski, 2020; Hasenohr, 2012; Karvonis, 2008; Karvonis \& Malmary, 2018; Trümper, 2008, 2011; Zarmakoupi, 2015,2018 a); relatively few studies have focused on the relation between spaces and their implications for the Delian urbanism (Bruneau, 1968; Fraisse, 1983, 2020; Fraisse \& Fadin, 2020; Marc, 2000). The image that emerges, however, is that a city whose historicity depends on the transformations of the middle of the second century, with little to do with the particular insularity built in the relation of Delos and the wider world along the previous centuries; buildings such as the temple of Mithridates, in that paradigm, appears to add little to the comprehension of the urbanism as a whole. When we consider Delos' insularity and integration fields, however, a new picture emerges.

The historical and cultural production of Delian insularity from Archaic to Early Hellenistic periods was studied by Chr. Constantakopoulou in two outstanding books (Constantakopoulou, 2010, 2017). In The dance of the islands, the author relates the island's reduced size and poverty in natural resources, the Aegean navigability facilitated by the profusion of islands and the knowledge of maritime currents and winds, the Archaic discourse of Delos as Apollo's birthplace, and the building of an Archaic religious network centered on the Delian central sanctuary. From those relations emerged images such as a 'chorus' of the Cycladic islands around Delos, as well the representation of the Delians as 'parasites of the god'. The Delian religious network, which included Ionian and Dorian communities, for Constantakopoulou, had a markedly insular, Cycladic character, attracting the attention of competing powers since the sixth century (such as Naxos, Samos, and Athens). That Cycladic network would eventually become, in the fifth century, the material basis upon which Athens built its empire over south 
Aegean, in a complex interaction with the Athenian 'Ionian propaganda' (Constantakopoulou, 2010, p. 61-89). In Aegean interactions (2017), dedicated to independent Delos (314-167), Constantakopoulou discussed the variety of strategies employed by Delian social groups to interact with the Early Hellenistic networks of social interaction (deaing especially with the epigraphic records of the sanctuary and the island's building activity), which operated on a much broader geographical scope than its regionally-framed economic networks, encompassing relations well beyond royal euergetism (Constantakopoulou, 2017, p. 21).

This long-term construction of Delian insularity suffered a deep change with the establishment of the Athenian cleruchy in 167/6. Athenian administration, , the free port status, the consequent commercial decline of Rhodes, and decisively the destruction of Corinth (in $146 \mathrm{BC}$ ) motivated an impressive urban growth with the establishment of trade colonies from all the Mediterranean, especially from Italy, Syria, and Egypt. At that point, a new element was added to the long history of Delian insularity construction (between religion and empire): the identity of Delos as a trade center, illustrated by a proverb quoted by Strabo: 'Merchant, sail in, unload your ship, everything has been sold' (Strabo, 14.5.2).

The Mithridatic Wars of the early first century would bring an abrupt end to this new amalgam of religious, imperial and commercial insularity: Delos would suffer two invasions by Pontic forces, in 89 and 69, virtually succumbing to the second. The abrupt demographic decline and the emergence Italian ports such as Puteoli and Ostia as Mediterranean trade centers deeply affected the Delian insularity, this time dominated by the topos of loneliness - according to Bruneau, due more to the contrast between its tiny population and the large number of unused buildings, than to an actual abandonment (Bruneau, 1968, p. 691-700).

The long history of Delian (urban) insularity produced a particular set of integration fields, each working according its own logic and exhibiting a particular arrangement of positions and frontiers. Here, five integration fields will be traced from the evidence available from the dedication of the temple of Mithridates in the Samothrakeion: the polis field, the imperial field, the religious field, the euergetic field and the commercial field.

The first is the polis field, visible both in the qualification of Helianax as Athenian and priest and in the mention to the Athenian people as co-dedicant (on the inscribed architrave) and as receiver of Mithridates' excellence and benevolence (on the inscribed statue base). The polis field encompassed the institutional relations between Athens and 
Delos, which regulates the main rules of government, the indication of magistrates, and concession of citizenship, as well as generated a peripheral cleruchy sub-field, produced by the dispute between magistrates and priests over positions in the island administration. Helianax's citizenship, if the hypothesis of a Rhodian family background is correct, illustrates the role played by the Delian cleruchy as a bridge to Athenian citizenship. Although previous views about the ephebia as automatically granting citizenship to enrolled foreigners has been criticized by recent scholars (Byrne, 2003; Oliver, 2013; Perrin-Saminadayar, 2005), it nonetheless facilitated the creation of social networks which could have led to the Assembly's approval for a request of enfranchising (Charade, 2009). Helianax's path to citizenship seems to be recent, as indicated both by the absence of demotic in the inscription of his father's portrait or his own demotic been the general 'from Athens', instead of indicating his particular Athenian demos. Although probably only recently enfranchised, Helianax was wealthy enough to build the temple and take of the cult activities at his own expenses; his wealth combined to a non-Athenian family background explains the prestigious, although not central, priesthood of the Great Gods, Kabeiroi, and Dioskouroi. The fragmentary inscription in the pediment, in its turn, which reveals only the honoree's ethnic ('from Amisos'), possibly points to the links between Athens and Amisos, where, in the fifth century, an Athenian cleruchy was installed (Erciyas, 2001, p. 160), though the lack of evidence prevents further hypotheses about possible personal relations between Helianax and the pediment's honoree.

The second is the imperial field, visible in the mentions to the Roman people, to Mithridates, and other Near Eastern kings and courtiers. Delos, being administered by a peripheral state such Athens, with no relevant military forces, had few options to protect itself in an increasingly dangerous environment. In the late second century, while the Roman republic was the undisputed power of the Mediterranean, Mithridates' expansion over the coasts of the Black Sea and Central Anatolia affected deeply the Near Eastern imperial field. By controlling Cappadocia, pressing Bithynia, and assuming the title of 'king of the kings' (at least in the Black Sea), Mithridates paralleled the Parthian emperor and accumulated the power which would sustain his wars against Rome, at the moment still an ally. The sample of honorees in the temple seems to reflect the political balance of the Near East: in the shield portraits, weaker, subordinated kings, such as Ariarathes of Cappadocia and Antiochos of Syria, were accompanied by members of Pontic and Parthian courts (as well Helianax's father), whilst Mithridates of Pontus received a freestanding statue with a cultic dimension. In this sense, it is understandable the absence of 
Mithridates II of Parthia, who himself could not be demoted to a shield portrait nor promoted, there, to a free-standing statue.

The third is the panhellenic religious field, visible in the associations between different cults. Contrarily to the other fields, Delos occupied here a central position derived from its centuries-long religious insularity: being the birthplace of Apollo, Delos has been the focus of an intense religious network which connected Aegean communities from the Archaic period onwards. This centrality was expressed in the central placement of the sanctuary of Apollo in the Delian urban fabric (Étienne, 2018, 2019). Conversely, the peripheral character of the cult of the Kabeiroi and the Great Gods of Samothrace in the Panhellenic religious landscape (Constantakopoulou, 2016) was expressed in its marginal placement in Delos, at the foot of mount Kynthos. For the role played by the Mithridates' cult, Ballesteros Pastor suggested a strong religious association between Pontic and Delian cults of the Kabeiroi and the Dioskouroi, both linked to the safe seafaring, as part of Mithridatic propaganda (Ballesteros Pastor, 2006), while Erciyas interprets the temple as a symbol of Mithridates' 'prominence in the Aegean among the Greeks and the other Hellenistic monarchies' (Erciyas, 2001, p. 115). However, despite being a rising imperial power, Mithridates could not aspire to a shrine near the sanctuary of Apollo or a festival in his honor. The only Hellenistic kings or queens worshiped at Delos, as noted by Bruneau, were Antigonus and Demetrios of Macedon, Arsinoe Philadelphia, and Mithridates; however, none of these cults were instituted by the Delians or the Athenian cleruchy: the first was created by the Nesiotic league in the fourth century, the second was instituted privately by a nesiarch named Hermias, and the third, as seen, by Helianax (Bruneau, 1970, p. 577-578). This contrasts sharply with the public cult of Rome, associated with Hestia and the personified Demos, accompanied by the festival of Rhomaia, since the beginning of the Athenian cleruchy (Bruneau, 1970, p. 444-446).

The fourth is the euergetic field, where individuals and communities disputed positions as benefactors of Delos. The centrality attributed to Delos in the panhellenic religious field transformed the island, early in the Archaic period, in one of the main stages for the display of euergetic practices, ranging from dedication of buildings to donations of land and mobile offerings of valuables. In exchange, the city honored the benefactor in proportional ways, from proclamations and honorific inscriptions to festivals and cult, according to the particular features of the Delian field (Tully, 2021). As seen above, in the Hellenistic period, only the deified Roman republic received public cult, given the benefaction of the island itself to the Athenians. Nonetheless, the euergetic 
field of Hellenistic Delos was open to multiple forms of competition. Helianax himself used two strategies: he dedicated a statue of Mithridates in the sanctuary of Apollo in the same year that he dedicated the temple in the Samothrakeion. Through the first strategy, he placed himself and Mithridates in the long list of private dedicants and honorees that filled virtually any corner of the sanctuary. Through the second one, he detached himself and his honoree from the rest, turning the Samothrakeion into an exclusive showcase for Mithridatic euergetism. As already noted, Helianax's choices for the shield portraits reveal his own personal connections (Roller, 2020, p. 129), which extended from the courts of Pontus and Parthia to the kings of Cappadocia and Syria (the latter was also honored by Helianax with a statue in the sanctuary of Apollo).

The fifth is the commercial field, where Delos gained centrality only in the second century, especially after the measures the Roman Senate took against Rhodes, revoking its possession over Lycia and Caria in 167, and the destruction of Corinth in 146. As Helianax's own career is not known, it is impossible to map his position in the commercial field, though his likely Rhodian family background points to a migration from a declining commercial center to a rising one. In the third century, Rhodes and Alexandria created the most secure - and most expensive - trade route in the Eastern Mediterranean, which enabled the island to become the main entrepôt of the Aegean, fighting piracy and developing banking and mass storage facilities (Gabrielsen, 2013). Along the second century, while Rhodes maintained a regional importance in the wheat and wine trade, Delos economic activity grew related to the slave trade and the commerce of luxury good from the East to Italy. The connections of Helianax to the Anatolian, Syrian, and Parthian courts could indicate his relation to the slave trade, given the role position of these regions as sources of slaves (Rostovtzeff, 1941, p. 771-798; Scheidel, 2011), but it remains hypothetical. Nonetheless, the multiple references to safe seafaring in the cult of the Great Gods, Kabeiroi and Dioskouroi both in Delos and Pontus (Ballesteros Pastor, 2006) suggests a connection of the dedication with maritime trade.

In sum, in the late second century, on the one hand, Delos conjugated central positions in the panhellenic religious field (due to the sanctuary of Apollo), the euergetic field (though competing with other center such as Athens and Delphi) and the commercial field (as redistribution entrepôt between the East and Italy); on the other hand, Delos was peripherally placed in the polis field, centered on Athens, and in the imperial field, centered in Rome. The Pontic kingdom under Mithridates VI, in that world, occupied a semi-peripheral position in the commercial field (through slave supply), the imperial field 
(between Rome and Parthia), and the euergetic field (less honored than Rome in euergetic centers such as Delos), with no participation in the Delian polis field. The centralities of Rome, Athens and Delos in different fields is manifested in the central placement of Athenian offices and Roman/Italian cults and buildings (such as the Agora of the Italians). The semi-peripherality of Pontus in its respective fields was manifest in the relatively marginal position of its temple in the Delian urban fabric.

Regarding its particular mode of integration, the temple of Mithridates illustrates the range of Helianax's personal network, with ultra-specialized contacts which would enable access to four of the main Near Eastern monarchies (Pontus, Parthia, Cappadocia and Syria) beyond the hierarchies defined by the imperial and polis fields, using the euergetic field in a way similar to that of contemporary global cities' integration to the global economic field. Through his dedication, Helianax, from a (probably) recently enfranchised Athenian family and holding a mid-level Delian priesthood, could express and reproduce his power derived from diplomatic and euergetic relations with semiperipheral imperial powers. The sample of honorees inside and outside the temple produced a map of Helianax's network, and as such indicated possible paths to anyone interested in creating bonds with the Black Sea, Central Anatolia and the Near East - a feature particularly important for slave traders. Helianax, then, could maximize his power combining capitals produced in different fields. Though we have no clue on the likely advantages the dedication of the temple gave to Helianax, we can see a parallel in the trajectory of Philostratos of Ascalon, who converted power accumulated in the commercial field into power reproduced in the polis and euergetic fields by receiving Neapolitan citizenship and the dedication of a portico in the Agora of the Italians (Hasenohr, 2015; Leiwo, 1989; Trümper, 2011). This 'global city' mode of integration, thus, is also found in other sites at Delos, such as the seat of the Poseidoniasts of Beirut and the Agora of the Italians, and mid-level sanctuaries, such as that of sanctuary of Serapis (Verdejo Manchado \& Antela-Bernárdez, 2015). This could be contrasted to the sanctuary of Apollo, whose mode of integration in the wider world derived from the accumulated centrality of Delos in the panhellenic religious field, a central feature of its insularity, with its own dense and wealthy religious regional network, through which Delos competed with Athens and Delphi, themselves resulting from similar accumulations. In that sense, I suggest, the sanctuary of Apollo's mode of integration was closer to that of contemporary 'world cities' and their territorial economies. 


\section{Conclusion}

The dedication by the Athenian priest Helianax of a temple to Mithridates VI of Pontus at Delos, was interpreted, in this paper, as a social action articulated by a set of structured spaces of intersocietal interaction - what have been here called integration fields. Rather than a single world-system or multiple globalizations, the integration field concept is sufficiently elastic to encompass multiple forms of interaction, and consistent enough to indicate the structured nature of particular integration processes. They result from complex and non-linear temporal strata and spatial scales. In the case of Delos, its particular urban insularity, built along many centuries, faced new challenges with the development of a new centrality in one strategic field - the commercial one. The ways groups and individuals interact with integration fields depends on their historically specific arrangement - integration fields are products as well as vectors of particular social actions. In the case of Helianax, the centralities of Delos in the commercial, panhellenic religious and euergetic fields, conjugated with the conjunctural rise of the Pontic kingdom in the Aegean subsystem of the imperial field, enabled the construction of a rhizomatic network that linked Delos to Anatolian, Syrian, and Parthian cities.

Rostovtzeff, quoted above, interpreted the history of Delos in the late second century as the passage from the temple to the port as the main social institution, replacing the polis by the cosmopolite agglomeration of mobile traders. As the discussion above showed, Delos remained a polis while incorporated the pressure generated by its new status as commercial center. Rather than a passage from the polis (temple) to the urban agglomeration (port), the process could be explained as a tension between the 'world city' (centered on the sanctuary and in the panhellenic religious field) and the 'global city' (spread over many places, with interactions primarily in the imperial and commercial fields) as modes of integration. This tension, in turn, reproduced and modulated the opposition between the traditional Attic aristocracy, which held the central offices in the polis field, and a new trading Delian elite, which explored the possibilities of the global city networks available at Delos (Antela-Bernárdez, 2009, 2015; Verdejo Manchado \& Antela-Bernárdez, 2015). The influence of multidirectional imperial expansion in the Mediterranean and the Near East in the late second century generated a profound social change in both macro-regions, with many extremely violent episodes in some strategic nodes, such as Athens and Delos. Thus, an integrated history of Delos, inspired in the recent debates on Global History, must be written - not least because we are struggling to understanding parallel processes in our own world. 
Fábio Augusto Morales, Mithridates, Helianax and the Late...

Article received in: 04/10/2021

Approved in: 08/12/2021 
Mare Nostrum, ano 2021, v. 12, n. 2

\section{BIBLIOGRAPHIC REFERENCES}

Amin, S. (2011). Global history: A view from the South. Pambazuka Press ; CODESRIA; Books for Change.

Anievas, A., \& Matin, K. (Orgs.). (2016). Historical sociology and world history: Uneven and combined development over the longue durée. Rowman \& Littlefield International.

Antela-Bernárdez, B. (2009). Entre Delos, Atenas, Roma y el Ponto: Medeo del Pireo. Faventia, 31(1), 49-60.

Antela-Bernárdez, B. (2015). Athenion of Athens Revisited*. Klio, 97(1).

Baldacchino, G. (2004). The Coming of Age of Island Studies. Tijdschrift Voor Economische En Sociale Geografie, 95(3), 272-283.

Baldacchino, G. (2018). The Routledge international handbook of island studies: A world of islands. Routledge, Taylor\&Francis group.

Ballesteros Pastor, L. (1995). Notas sobre una inscripción de Ninfeo en honor de Mitrídates Eupátor, rey del Ponto. Dialogues d'histoire ancienne, 21(1), 111-117.

Ballesteros Pastor, L. (1998). El Ponto visto por Estrabón. Orbis Terrarum, 4, 55-61.

Ballesteros Pastor, L. (2006). Los cultos de Mitrídates Eupátor en Delos: Una propuesta de interpretación. Habis, 37, 209-216.

Ballesteros Pastor, L. (2018a). De rey del Ponto a rey de reyes. El imperio de Mitrídates Eupátor en el contexto del Oriente tardo-helenístico. In L. R. Cresci \& F. Gazzano (Orgs.), De Imperiis. L'idea di impero universale e la successione degli imperi nell'Antichità (p. 137-170). L'Erma di Bretschneider.

Ballesteros Pastor, L. (2018b). Les réseaux de Mithridate. Dialogues d'histoire ancienne, 44(1), 273-303.

Bang, P. F., \& Bayly, C. A. (Orgs.). (2011). Tributary Empires in Global History. Palgrave Macmillan UK.

Beckert, S., \& Sachsenmaier, D. (2018). Global History, Globally: Research and Practice around the World. Bloomsbury Academic.

Belich, J., Darwin, J., Frenz, M., \& Wickham, C. (Orgs.). (2016). The prospect of global history (First edition). Oxford University Press.

Benoist, J. (1987). L'insularité comme dimension du fait social. Îles et Archipels, 8(1), $36-44$.

Boomert, A., \& Bright, A. (2007). Island Archaeology: In Search of a New Horizon. Island Studies Journal, 2. 
Broodbank, C. (2002). An Island Archaeology of the Early Cyclades. Cambridge University Press.

Bruneau, P. (1968). Contribution à l'histoire urbaine de Délos. Bulletin de correspondance hellénique, 92(2), 633-709.

Bruneau, P. (1970). Recherches sur les cultes de Délos à l'époque hellénistique et à l'époque impériale. Editions E. de Boccard.

Bruneau, P., Brunet, M., Farnoux, A., \& Moretti, J.-C. (Orgs.). (2013). Le commerce à Délos. In Délos: Île sacrée et ville cosmopolite (p. 103-109). CNRS Éditions.

Buchholz, L. (2008). Field Theory and Globalization. After Bourdieu, 211-238.

Buchholz, L. (2016). What is a Global Field? Rethinking Bourdieu's Field Theory beyond the Nation-State. The Sociological Review Monographs, 25.

Byrne, S. G. (2003). Early Roman Athenians. In Athens Symposium, J. Kirchner, J. S. Traill, D. R. Jordan, Canadian Archaeological Institute at Athens, Ont. ) Victoria University (Toronto, \& Athenians Research Project (Orgs.), Lettered Attica: A day of Attic epigraphy: Actes du Symposium d'Athènes, 8 mars 2000 ; avec un mémoire (p. 1-20). Canadian Archaeological Institute at Athens = Institut canadien d'archéologie à Athenes.

Campos, R. da C. (2013). Entre Roma e Capri: O afastamento de Tibério César como ponto de inflexão política durante seu Principado (14-37 d.C.) [Doutorado em História Social, Universidade de São Paulo].

Carvalho, M. D. (2000). Cidade global: Anotações críticas sobre um conceito. São Paulo em Perspectiva, 14, 70-82.

Chankowski, V. (2020). Stockage et distribution: Un enjeu dans les circuits économiques du monde grec. In X. Lafon \& C. Virlouvet (Orgs.), Entrepôts et circuits de distribution en Méditerranée antique (p. 15-42). École française d'Athènes.

Chapouthier, F. (1935). Le sanctuaire des Dieux de Samothrace. École française d'Athènes.

Charade, S. (2009). L'intégration politique, sociale et religieuse des Rhômaioi dans les cités d'Athènes et de Délos (de la basse époque hellénistique jusqu'au règne des Julio-Claudiens). Université du Québec à Montréal.

Christodoulou, S. (2015). The Pontic Kingdom Under Mithridates VI. Balkan Studies, 40.

Cole, S. G. (1984). Theoi Megaloi: The Cult of the Great Gods at Samothrace (Illustrated edition). Brill. 
Conrad, S. (2016). What is global history? Princeton University Press.

Constantakopoulou, C. (2010). The dance of the islands: Insularity, networks, the Athenian empire and the Aegean world. Oxford University Press.

Constantakopoulou, C. (2016). Centrality and Peripherality: Insularity and the Appeal of the Religious Networks of Delos and Samothrace in the Classical and Hellenistic Periods. In N. Jaspert, S. Kolditz, R. von Bendemann, \& A. Gerstenberg (Orgs.), Konstruktionen mediterraner Insularitäten (p. 75-93). Brill | Schöningh.

Constantakopoulou, C. (2017). Aegean Interactions: Delos and its Networks in the Third Century (Vol. 1). Oxford University Press.

Crossley, P. K. (2008). What Is Global History? (Illustrated edição). Polity Press.

Derudder, B. (2012). Global city/world city. In B. Derudder (Org.), International handbook of globalization and world cities (p. 73-81). Edward Elgar.

Derudder, B., Hoyler, M., Taylor, P., \& Witlox, F. (2011). International Handbook of Globalization and World Cities. Edward Elgar Publishing.

Drayton, R., \& Motadel, D. (2018). Discussion: The futures of global history. Journal of Global History, 13(1), 1-21.

Durrbach, F. (1921). Choix d'inscriptions de Délos. Ernest Leroux.

Erciyas, D. B. A. (2001). Studies in the Archaeology of Hellenistic Pontus: The Settlements, Monuments, and Coinage of Mithradates VI and his Predecessors. University of Cincinnati.

Erciyas, D. B. A. (2005). Wealth, Aristocracy and Royal Propaganda Under the Hellenistic Kingdom of the Mithradatids in the Central Black Sea Region of Turkey. Brill Academic Publishers.

Étienne, R. (Org.). (2018). Le sanctuaire d'Apollon à Délos Tome I, Architecture, topographie, histoire. (Illustrated édition). Ecole française d'Athènes.

Étienne, R. (Org.). (2019). Le Sanctuaire d'Apollon à Délos Tome II, Les monuments votifs et honorifiques (Illustrated édition). Ecole française d'Athènes.

Ferreira, J. S. W. (2007). O Mito Da Cidade Global. O Papel Da Ideologia Na Produção Do Espaco Urbano ( $1^{\mathrm{a}}$ edição). Vozes.

Fix, M. (2007). São Paulo cidade global: Fundamentos financeiros de uma miragem (Anpur). Boitempo.

Fraisse, P. (1983). Analyse d'espaces urbains: Les «places» à Délos. Bulletin de correspondance hellénique, 107(1), 301-313. 
Fraisse, P. (2020). Délos: Études de morphologie urbaine I Objectifs et méthodes. Bulletin de correspondance hellénique, 144.1, Article 144.1.

Fraisse, P., \& Fadin, L. (2020). Délos: Études de morphologie urbaine II. Bulletin de correspondance hellénique, 144.1, Article 144.1.

Friedmann, J. (1986). The World City Hypothesis. Development and Change, 17(1), 6983.

Friedmann, J. (2001). World cities revisited: A comment. Urban Studies, 2535-2536.

Friedmann, J., \& Wolff, G. (1982). World city formation: An agenda for research and action. International Journal of Urban and Regional Research, 6(3), 309-344.

Gabrielsen, V. (2013). Rhodes and the Ptolemaic kingdom: The commercial infrastructure. In D. J. Thompson, K. Buraselis, \& M. Stefanou (Orgs.), The Ptolemies, the Sea and the Nile: Studies in Waterborne Power (p. 66-81). Cambridge University Press.

Gettel, E. (2018). Recognizing the Delians Displaced after 167/6 BCE. Humanities, 7(4), 91.

Ghadge, R. (2019). Toward a Critical Understanding of the World/ Global City Paradigm. 11, 1.

Gills, B., \& Frank, A. G. (Orgs.). (1996). The World System: Five Hundred Years or Five Thousand? (Revised ed. edição). Routledge.

Ginouvès, R. (1993). La Macédoine: De Philippe II à la conquête romaine. CNRS Éditions.

Grydehøj, A. (2015). Island city formation and urban island studies. Area, 47(4), 429435.

Grydehoj, A., Pinya, X. B., Cooke, G., Doratli, N., Elewa, A., Kelman, I., Pugh, J., Schick, L., \& Swaminathan, R. (2015). Returning from the Horizon: Introducing Urban Island Studies. Urban Island Studies, 1, 1-19.

Guarinello, N. L. (2003). Uma morfologia da História: As formas da História Antiga. Politeia: História e Sociedade (Vitória da Conquista), 3(1), 41-61.

Guarinello, N. L. (2010). Ordem, Integração e Fronteiras no Império Romano: Um Ensaio. Mare Nostrum, 1(1), 113-127.

Guarinello, N. L. (2013). História antiga (1 ${ }^{\mathrm{a}}$ edição). Editora Contexto.

Guarinello, N. L. (2014). Ensaios sobre História Antiga. Faculdade de Filosofia, Letras e Ciências Humanas. Universidade de São Paulo. 
Mare Nostrum, ano 2021, v. 12, n. 2

Habicht, C. (1997). Athens from Alexander to Antony (D. L. Schneider, Trad.; 1st edition). Harvard University Press.

Hall, P. (1966). The world cities. McGraw-Hill.

Hansen, M. H. (Org.). (2000). A Comparative Study of Thirty City-State Cultures: An Investigation Conducted by the Copenhagen Polis Centre. Kongelige Danske Videnskabernes Selskab.

Hansen, M. H., Københavns universitet, \& Polis centret. (2002). A comparative study of six city-state cultures: An investigation. Kongelige Danske Videnskabernes Selskab : Commission Agent, C.A. Reitzels Forlag.

Hasenohr, C. (2012). Athènes et le commerce délien: Lieux d'échange etmagistrats des marchés à Délos pendant la secondedomination athénienne (167-88 a.C.). In K. Konuk (Org.), Stephanèphoros: De l'économie antique à l'Asie Mineure: Hommages à Raymond Descat (p. 95-109). Ausonius.

Hasenohr, C. (2015). Italiens et Phéniciens à Délos: Organisation et relations de deux groupes d'étrangers résidents (iie-ier siècles av. J.-C.). In R. CompatangeloSoussignan \& C.-G. Schwentzel (Orgs.), Étrangers dans la cité romaine: " "Habiter une autre patrie”: Des incolae de la République aux peuples fédérés du Bas-Empire » (p. 77-90). Presses universitaires de Rennes.

Hodos, T. (2006). Local responses to colonization in the Iron Age Mediterranean. Routledge.

Hodos, T., \& Geurds, A. (Orgs.). (2017). The Routledge handbook of archaeology and globalization. Routledge.

Højte, J. M. (Org.). (2009). Mithridates VI and the Pontic Kingdom. Aarhus University Press.

Horden, P., \& Purcell, N. (2000). The Corrupting Sea: a Study of Mediterranean History. Wiley-Blackwell.

Houston, G. W. (1985). Tiberius on Capri. Greece \& Rome, Second Series, 32(2), 179196.

Karras, A. L., Mitchell, L. J., \& Bentley, J. H. (Orgs.). (2017). Encounters Old and New in World History: Essays Inspired by Jerry H. Bentley. University of Hawai'i Press.

Karvonis, P. (2008). Les installations commerciales dans la ville de Délos à l'époque hellénistique. Bulletin de Correspondance Hellénique, 132(1), 153-219. 
Karvonis, P., \& Malmary, J.-J. (2018). Le stockage dans les installations commerciales. In V. Chankowski, X. Lafon, \& C. Virlouvet (Orgs.), Entrepots et circuits de distribution en Mediterranee antique (Vol. 58, p. 169-194). Peeters Publishers.

Kay, P. (2014). Rome's economic revolution (First Edition). Oxford University Press.

Knappett, C. (2011). An Archaeology of Interaction: Network Perspectives on Material Culture and Society. Oxford University Press.

Knappett, C., \& Society for American Archaeology (Orgs.). (2013). Network analysis in archaeology: New approaches to regional interaction (1st ed). Oxford University Press.

Knox, P. P. L., \& Taylor, P. J. (Orgs.). (1995). World Cities in a World-System. Cambridge University Press.

Kouremenos, A. (2018). Insularity and identity in the Roman Mediterranean. Oxbow.

Kouremenos, A., \& Gordon, J. M. (Orgs.). (2020). Mediterranean Archaeologies of Insularity in an Age of Globalization. Oxbow Books.

Kreuz, P.-A. (2009). Monuments for the King: Royal Presence in the Late Hellenistic World of Mithridates VI. In J. M. Hojte (Org.), Mithridates VI and the Pontic Kingdom (Illustrated edition, p. 131-144). Aarhus University Press.

LaBianca, O. S., \& Scham, S. A. (2014). Connectivity in Antiquity: Globalization as a Long-Term Historical Process (1st edition). Routledge.

Leidwanger, J., \& Knappett, C. (Orgs.). (2018). Maritime Networks in the Ancient Mediterranean World ( $1^{\mathrm{o}}$ ed). Cambridge University Press.

Leiwo, M. (1989). Philostratus of Ascalon, his bank, his connections and Naples in c. 130-90 BC. Athenaeum, 1989(n.s. 77), 575-584.

Lloyd, G. E. R., Zhao, J. J., \& Dong, Q. (Orgs.). (2018). Ancient Greece and China Compared (1st edition). Cambridge University Press.

Marc, J.-Y. (2000). Combien y avait-il d'agoras à Délos ? Ktèma, 25(1), 41-45.

Marcade, J. (1969). Au musée de Délos: Étude sur la sculpture hellénistique en ronde bosse découverte dans l'île. E. de Boccard.

Mattingly, H. B. (2004). From Coins to History: Selected Numismatic Studies. University of Michigan Press.

Mazlish, B. (1998). Comparing Global History to World History. The Journal of Interdisciplinary History, 28(3), 385-395.

McGing, B. C. (1997). The Foreign Policy of Mithridates VI Eupator, King of Pontus. Brill Academic Pub. 
Morales, F. A., \& Silva, U. G. da. (2020). História Antiga e História Global: Afluentes e confluências. Revista Brasileira de História, 40(83), 125-150.

Moretti, J.-C. (2015). L'architecture publique à Délos au IIIe s. A.C. In J. Des Courtils (Org.), L'architecture monumentale grecque au IIIe s. A.C. (p. 83-115). Ausonius.

Morris, I. (2003). Mediterraneanization. Mediterranean Historical Review, 18(2), 30-55.

Mutschler, F.-H., \& Mittag, A. (Orgs.). (2008). Conceiving the empire: China and Rome compared. Oxford University Press.

Oliver, G. J. (2013). Citizenship: Inscribed honours for individuals in Classical and Hellenistic Athens. In J.-C. Couvenhes \& S. Milanezi (Orgs.), Individus, groupes et politique à Athènes de Solon à Mithridate (p. 273-292). Presses universitaires François-Rabelais.

Olstein, D. (2015). Thinking History Globally. Palgrave Macmillan UK.

Osborne, R., \& Wallace-Hadrill, A. (2013). Cities of the Ancient Mediterranean. In P. Clark (Org.), The Oxford Handbook of Cities in World History (p. 49-65). Oxford University Press.

Parker, R. (2017). Greek gods abroad: Names, natures, and transformations. University of California Press.

Patton, M. (2013). Islands in Time Island Sociogeography and Mediterranean Prehistory.

Perrin-Saminadayar, É. (2005). Image, statut et accueil des étrangers à Athènes à l'époque hellénistique. In Le barbare, l'étranger: Images de l'autre: Actes du colloque organisé par le CERHI, Saint-Etienne, 14 et 15 mai 2004 (p. 67-91). Publications de l'Université de Saint-Étienne.

Pitts, M., \& Versluys, M. J. (Orgs.). (2014). Globalisation and the Roman world: World history, connectivity and material culture. Cambridge University Press.

Purcell, N. (2016). Unnecessary Dependences: Illustrating Circulation in Pre-modern Large-scale History. In J. Belich, J. Darwin, M. Frenz, \& C. Wickham (Orgs.), The prospect of global history (First edition, p. 65-79). Oxford University Press.

Rauh, N. K. (1993). The Sacred Bonds of Commerce: Religion, Economy, and Trade Society at Hellenistic Roman Delos, 166-87 B.C. (Illustrated edição). J.C. Gieben.

Roller, D. W. (2020). Empire of the Black Sea: The rise and fall of the Mithridatic world. Oxford University Press.

Rostovtzeff, M. (1941). Economic History of the Hellenistic World (Vol. 2). Clarendon Press. 
Fábio Augusto Morales, Mithridates, Helianax and the Late...

Sachsenmaier, D. (2011). Global Perspectives on Global History: Theories and Approaches in a Connected World. Cambridge University Press.

Sassen, S. (2001). The Global City: New York, London, Tokyo (2nd Revised ed. edição). Princeton University Press.

Sassen, S. (2005). The Global City: Introducing a Concept. The Global City, 2, 18.

Scheidel, W. (Org.). (2009). Rome and China: Comparative perspectives on ancient world empires. Oxford University Press.

Scheidel, W. (2011). The Roman slave supply. In K. Bradley \& P. Cartledge (Orgs.), The Cambridge World History of Slavery (p. 287-310). Cambridge University Press.

Sitz, A. M. (2017). The Writing On The Wall: Inscriptions And Memory In The Temples Of Late Antique Greece And Asia Minor. University of Pennsylvania.

Taylor, P. J. (2003). World City Network: A Global Urban Analysis (1st edition). Routledge.

Taylor, P. J., Witlox, F., Derudder, B., \& Catalano, G. (2003). Beyond Friedmann's world city hypothesis: Twenty two urban arenas across the world. Mitteilungen der Osterreichischen Geographischen Gesellschaft, 145, 35-55.

Trümper, M. (2008). Die “Agora des Italiens” in Delos: Baugeschichte, Architektur, Ausstattung und Funktion einer späthellenistischen Porticus-Anlage (1., Edition). VML Vlg Marie Leidorf.

Trümper, M. (2011). Where the Non-Delians met in Delos: The Meeting-Places of Foreign Associations and Ethnic Communities in Late Hellenistic Delos. In Political Culture in the Greek City after the Classical Age (p. 49-100). Peeters Publishers.

Tully, J. (2021). Socially Embedded Benefaction on Delos. In A. Zuiderhoek \& M. Domingo Gygax (Orgs.), Benefactors and the Polis: The Public Gift in the Greek Cities from the Homeric World to Late Antiquity (p. 179-198). Cambridge University Press.

Verdejo Manchado, J., \& Antela-Bernárdez, B. (2015). Pro-Mithridatic and Pro-Roman Tendencies in Delos in the Early First Century BC: The case of Dikaios of Ionidai (ID 2039 and 2040). Dialogues d'histoire Ancienne, 41/1(1), 117.

Vlassopoulos, K. (2013). Greeks and barbarians. Cambridge University Press.

Wilkinson, T. C., Sherratt, S., \& Bennet, J. (Orgs.). (2011). Interweaving worlds: Systemic interactions in Eurasia, 7th to 1st millennia BC. Oxbow Books. 
Mare Nostrum, ano 2021, v. 12, n. 2

Woolf, G. (2020). The Life and Death of Ancient Cities: A Natural History. Oxford University Press.

Zarmakoupi, M. (2015). Les maisons des négociants italiens à Délos: Structuration de l'espace domestique dans une société en mouvement. Cahiers «Mondes anciens », 7.

Zarmakoupi, M. (2018a). Le stockage dans les maisons: Entre économie domestique et économie «portuaire. In V. Chankowski, X. Lafon, \& C. Virlouvet (Orgs.), Entrepots et circuits de distribution en Mediterranee antique (Vol. 58, p. 195208). Peeters Publishers.

Zarmakoupi, M. (2018b). The urban development of late Hellenistic Delos. In S. L. Martin-Mcauliffe \& D. Millete (Orgs.), Ancient Urban Planning in the Mediterranean (p. 28-49). Routledge.

Zuiderhoek, A. (2017). The Ancient City. Cambridge University Press. 


\title{
Mitridates, Helianax E Delos No Período Helenístico Como Cidade Global: Insularidade Urbana E CaMpos De InTEgração
}

\author{
Fábio Augusto Morales
}

\section{RESUMO}

Este artigo discute o problema da mediação entre as escalas macro e micro na História Global, centrando-se na análise da dedicação do templo de Mitridates por um certo Helianax, no ano de 102/1 a.C., no santuário dos deuses da Samotrácia em Delos. Após descrever os vestígios arqueológicos e epigráficos, o artigo discute os conceitos de insularidade urbana, cidade mundial/global e campos de integração, para então explorar sua capacidade explicativa na análise dos campos de integração e modos particulares de integração visíveis na dedicação de Helianax.

PALAVRAS-CHAVE

Insularidade urbana, Campos de integração, Delos helenística. 